\title{
PENYAKIT KAWASAKI
}

\author{
F.X. Wikan Indrarto \\ Rumah Sakit Bethesda \\ Fakultas Kedokteran Universitas Kristen Duta Wacana \\ Korespondensi: fxwikan_indrarto@yahoo.com
}

\begin{abstract}
ABSTRAK
Penyakit Kawasaki adalah sebuah sindrom vaskulitis akut yang dominan mempengaruhi arteri kecil dan menengah, terutama mengenai anak balita. Gejala klinis penyakit Kawasaki sering dimulai dengan demam tinggi dan terus-menerus selama 2 minggu.

Penyakit Kawasaki hanya dapat didiagnosis secara klinis dan tidak ada pemeriksaan laboratorium yang khusus. Diagnosis klinis berdasarkan adanya demam 5 hari, ditambah 4 dari 5 kriteria diagnostik berikut ini: (1) eritema bibir atau rongga mulut atau retak bibir, (2) ruam kulit, (3) pembengkakan pada tangan atau kaki, (4) mata merah (injeksi konjungtiva), dan (5) pembesaran getah bening di leher minimal 15 milimeter.

Anak dengan penyakit Kawasaki mudah terjadi komplikasi aneurisma arteri koroner, terutama pasien yang tidak diobati secara dini dalam perjalanan penyakit. IVIG (imunoglobulin per infus) sebaiknya diberikan dalam dosis tinggi, yaitu $2 \mathrm{gr} /$ kgBB selama 10-12 jam. Terapi aspirin dimulai pada dosis tinggi 80-100 mg/kgBB/ hari dalam 4 dosis sampai 2-3 hari demam mereda, dan kemudian dilanjutkan dengan dosis rendah 3-5 mg/kgBB/hari, ketika pasien diijinkan pulang ke rumah.

Meskipun tidak diobati, sebenarnya gejala penyakit Kawasaki yang akut juga membaik, tetapi risiko terjadinya aneurisma arteri koroner jauh lebih besar. Tidak dikenal cara pencegahan untuk penyakit Kawasaki. Pencegahan dilakukan untuk menghindari perburukan kerusakan koroner.
\end{abstract}

Kata Kunci: kawasaki, diagnosis, treatment, prognosis 


\title{
KAWASAKI DISEASE
}

\author{
F.X. Wikan Indrarto \\ Bethesda Hospital Yogyakarta \\ Medical Faculty of Duta Wacana Christian University
}

Correspondence: fxwikan_indrarto@yahoo.com

\begin{abstract}
Kawasaki Disease is an acute vasculitis syndrome which affects predominantly at small and medium sized arteries, especially on children under five. Clinical symptoms of Kawasaki disease often begins with a high fever and continuously for two weeks.

Kawasaki Disease can only be diagnosed clinically and no specific laboratory test. The clinical diagnosis based on the presence of fever 5 days, plus 4 of 5 following diagnostic criteria: (1) erythema of the lips or mouth or cracked lips, (2) rash, (3) swelling of the hands or feet, (4) red eyes (conjunctival injection), and (5) enlarged lymph nodes in the neck of at least 15 millimeters.

Children with Kawasaki Disease easily occur complications of coronary artery aneurysm, especially patients who are not treated in the early course of disease. IVIG (immunoglobulin per infusion) should be given in high doses, ie $2 \mathrm{~g} / \mathrm{kg}$ for 10-12 hours. Aspirin therapy is started at high doses of $80-100 \mathrm{mg} / \mathrm{kg} /$ day in 4 doses up to 2-3 days free of fever, and then followed by low dose of 3-5 $\mathrm{mg} / \mathrm{kg} /$ day.

Although it is not treated, the actual symptoms of acute Kawasaki Disease also improved, but the risk of coronary artery aneurysms are much greater. No preventive intervention for Kawasaki Disease. Prevention is done to avoid worsening coronary damage.
\end{abstract}

Keywords: kawasaki, diagnosis, treatment, prognosis 


\section{DEFINISI}

Penyakit Kawasaki adalah sebuah sindrom vaskulitis akut yang dominan mempengaruhi arteri kecil dan menengah. Data epidemiologis menunjukkan bahwa aspek genetika anak mendasari patogenesis penyakit ini. ${ }^{1}$ Penyakit Kawasaki (juga dikenal sebagai sindrom kelenjar getah bening, penyakit simpul mukokutan, dan poliarteritis anak) adalah penyakit vaskulitis dan $80 \%$ pasien adalah balita, yang mengenai banyak organ, termasuk kulit, selaput lendir, kelenjar getah bening, dan dinding pemvbuluh darah. Efek yang paling serius adalah pada jantung yang dapat menyebabkan dilatasi pembuluh darah atau aneurisma. Tanpa pengobatan, kematian dapat mendekati $1 \%$, yang biasanya terjadi dalam waktu 6 minggu sejak sakit.

Penyakit ini pertama kali dijelaskan pada tahun 1967 oleh Dr. Tomisaku Kawasaki di Jepang, sehingga disebut Penyakit Kawasaki. Sejauh ini insiden penyakit Kawasaki tertinggi terjadi di Jepang (175 per 100.000 anak). Sebuah hipotetis patogenesis penyakit Kawasaki adalah "sistem homeostasis protein", yaitu setelah sebuah infeksi oleh patogen yang tidak diketahui, protein patogen yang dihasilkan menyebar dan mengikat sel endothelial arteri koroner sebagai sel target utama. ${ }^{2}$ Hal ini mungkin saja dipengaruhi oleh sebuah gen pada anak di Jepang, yang diduga memberikan kontribusi untuk kerentanan terhadap penyakit Kawasaki, lesi arteri koroner, resistensi terhadap pengobatan, gejala klinis penyakit Kawasaki yang tidak lengkap, dan penanda klinis lainnya. ${ }^{3}$ Perubahan ekspresi gen CASP3 dalam sistem kekebalan sel efektor berpengaruh terhadap kerentanan seorang anak, untuk menderita penyakit kawasaki. ${ }^{1}$ Selain itu, polimorfisme sel dendritik (DC-SIGN, CD209) telah menunjukkan fungsinya yang memicu kaskade anti-inflamasi dan terkait dengan kerentanan seorang anak terhadap penyakit Kawasaki. ${ }^{4}$

\section{GEJALA}

Gejala klinis penyakit Kawasaki sering dimulai dengan demam tinggi dan terus-menerus, yang tidak responsif terhadap dosis normal obat turun demam parasetamol (acetaminophen) atau ibuprofen. Demam dapat bertahan terus selama 2 minggu dan biasanya disertai mudah marah dan anak menjadi emosional. Gejala klinis yang umum meliputi :

1. Demam tinggi (lebih dari $39^{\circ} \mathrm{C}$ ) yang biasanya berlangsung selama lebih dari 5 hari.

2. Mata merah (konjungtivitis) tanpa sekret, juga dikenal sebagai "injeksi konjungtiva"

3. Bibir berwarna merah terang, pecah-pecah, atau retak.

4. Selaput lendir di mulut juga merah.

5. Lidah merah dengan benjolan (papillae) di bagian belakang (lidah strawberry).

6. Telapak tangan dan telapak kaki berwarna kemerahan.

7. Ruam kulit dengan banyak bentuk

8. Bengkak kelenjar getah bening hanya satu sisi, terutama di daerah leher.

9. Sakit sendi (arthralgia) dan pembengkakan yang simetris.

10. Lekas marah atau emosional.

11. Tachycardia (detak jantung cepat)

12. Telapak tangan dan telapak kaki mengelupas (desquamation) mulai dari sekitar kuku. Juga ada Garis Beau's (garis putih melintang pada paku). 

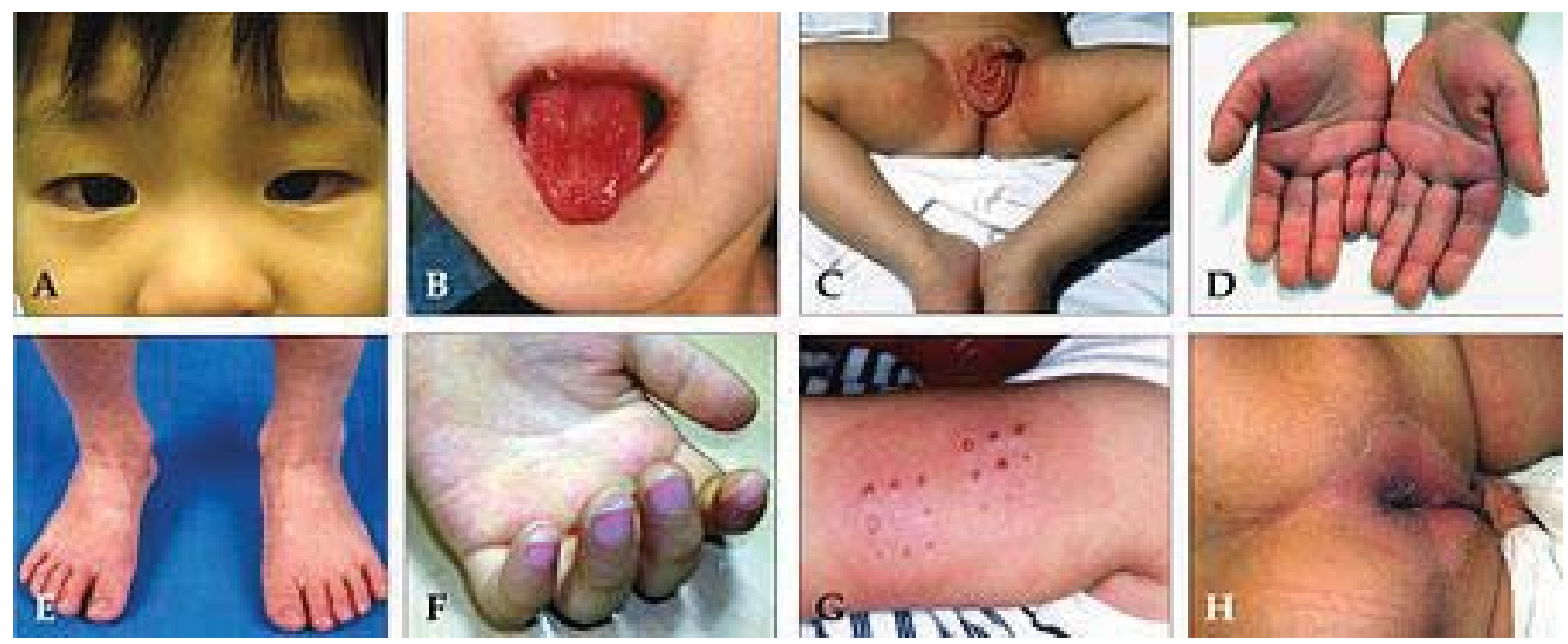

Gambar 1. Gambaran klinik penyakit Kawasaki. ${ }^{5}$

A. Konjungtivitis bilateral non eksudatif, dengan konjungtiva kemerahan (conjunctival injection).

B. Lidah strawberry (strawberry tongue), merah cerah, bibir bengkak dengan lecet vertikal dan perdarahan.

C. Kemerahan kulit (erythematous rash) sampai di daerah perineum.

D. Kemerahan (erythema) telapak tangan, disertai nyeri dan bengkak pada punggung tangan.
E. Kemerahan (erythema) telapak kaki, disertai nyeri dan bengkak pada punggung kaki.

F. Kulit pada jari mengelupas (desquamation).

G. Kemerahan (erythema) dan penebalan (induration) pada bekas sintikan imunisasi BCG.

H. Kulit sekitar anus mengelupas (desquamation).

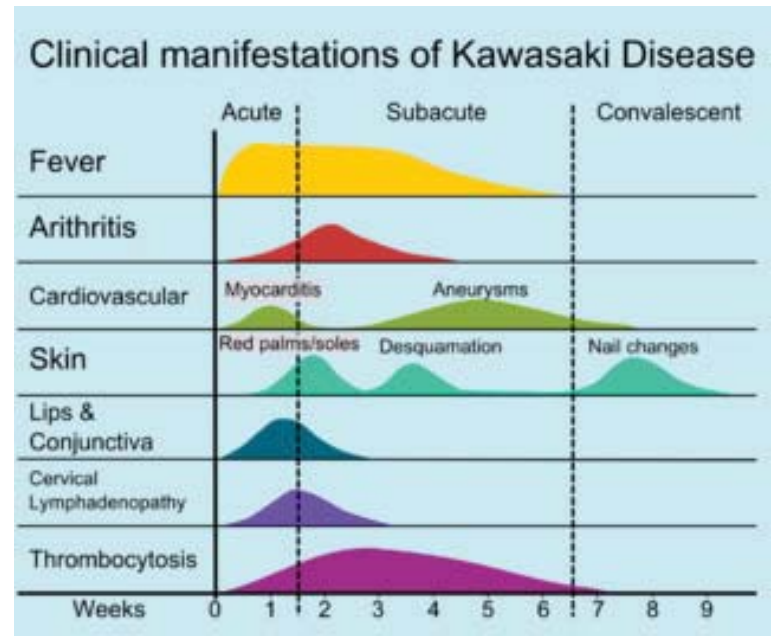

Gambar 2. Gambaran manifestasi klinik penyakit Kawasaki dan periodisasinya. ${ }^{5}$ 


\section{KOMPLIKASI}

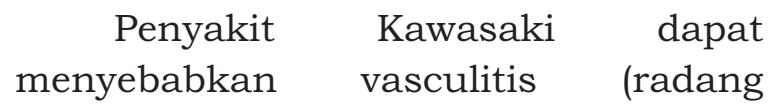
pembuluh darah), terutama pada jantung. Lesi jantung dapat berupa dilatasi koroner (76\%), aneurisma koroner (4\%), aneurisma koroner besar $(0,6 \%)$, penyempitan koroner $(0,3 \%)$, dan lesi katup (20\%). ${ }^{6}$ Aneurisma ini dapat mengakibatkan infark miokard (serangan jantung) pada anak.

Anak dengan penyakit Kawasaki mudah terjadi komplikasi aneurisma arteri koroner, terutama pasien yang tidak diobati secara dini dalam perjalanan penyakit. Selain itu, usia pasien anak dapat dijadikan prediktor untuk terjadinya lesi arteri koroner, yaitu aneurisme berbentuk huruf $U$ pada bagian bawah jantung, yaitu

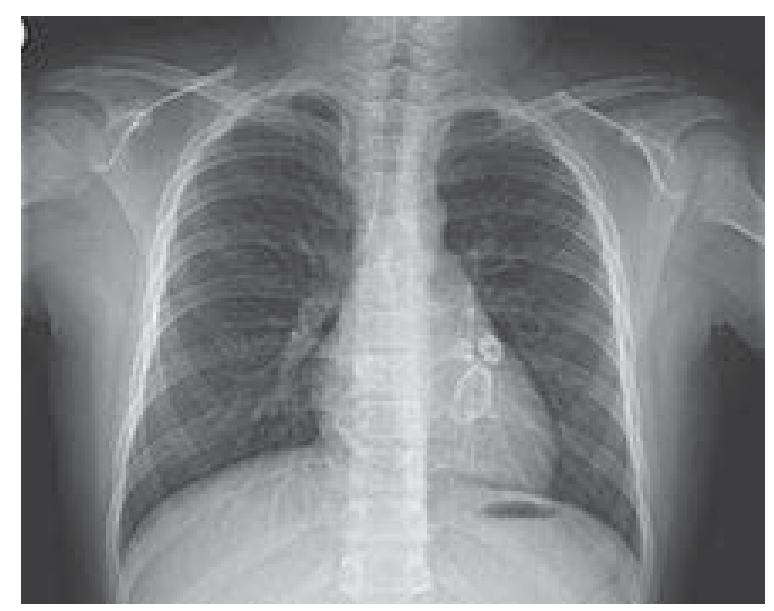

Gambar 3. Foto Rontgen polos dada yang menunjukkan aneurisma besar pada arteri koronaria. ${ }^{5}$ usia<11 bulan (OR 3,0, 95\% CI 1,4-6,6) dan $>48$ bulan (OR 3,1, 95\% CI 1,5$6,6) \cdot{ }^{7}$ Selain itu, adanya polimorfisme sel denritik CD209 bertanggung jawab atas kerentanan seorang anak mengalami penyakit Kawasaki, meskipun tidak berhubungan dengan pembentukan aneurisme dan respon pengobatan. ${ }^{4}$ Faktor-faktor yang berhubungan dengan komplikasi aneurisma koroner adalah jumlah platelet lebih tinggi (OR 1,01) dan albumin rendah (OR 0,34), meskipun demikian tidak ada faktor yang secara signifikan berhubungan dengan aneurisma koroner sangat besar. Faktor yang terkait lesi katup jantung adalah usia lebih muda (RO 0,98), dan CRP yang lebih tinggi (RO 1,05). ${ }^{6}$

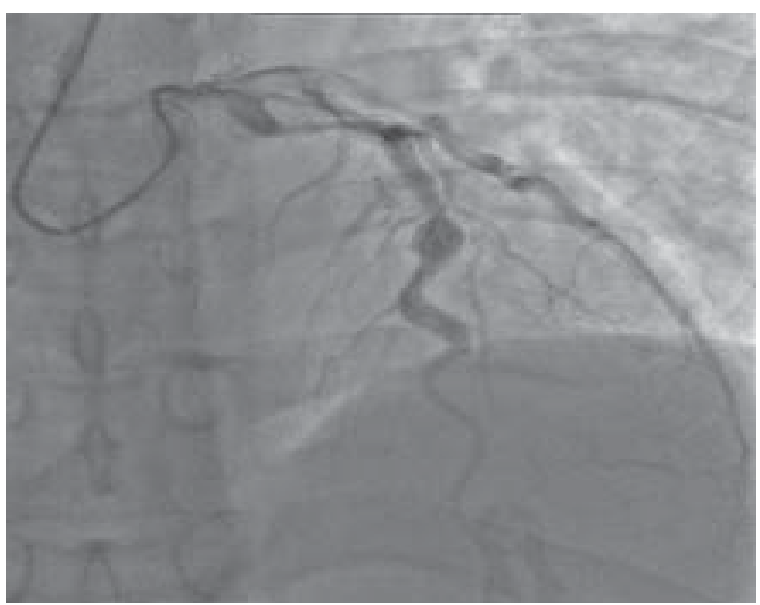

Gambar 4. Pemeriksaan angiografi yang menunjukkan aneurisma besar, dengan diameter $6,5 \mathrm{~mm}^{5}$

menegakkan diagnosis, terutama pada awal perjalanan penyakit. Selain itu, banyak penyakit serius lainnya dapat menyebabkan gejala serupa, dan harus dipertimbangkan dalam diagnosis banding, termasuk demam berdarah Dengue, sindrom syok toksik, juvenil idiopatik artritis, dan anak keracunan merkuri (acrodynia). 
Pada penyakit Kawasaki cukup sering (not uncommon) disertai adanya infeksi Human Adenovirus (HadV), meskipun mungkin merupakan infeksi persisten HAdV, sehingga harus ditafsirkan dengan hati-hati. Selain itu, penelitian lebih lanjut diperlukan untuk mengungkapkan hubungan infeksi mikroba, misalnya Streptococcus spp, atau virus dengan patogenesis penyakit Kawasaki. ${ }^{7}$ Dengan pemeriksaan reaksi berantai polimerase (PCR) kuantitatif dan deteksi molekuler HadV, dapat membantu dalam membedakan penyakit infeksi HAdV yang menyerupai Kawasaki (mimicking) dari Kawasaki dengan infeksi HAdV yang bersamaan (concomitant). ${ }^{9}$ Meskipun limfadenitis leher (cervical lymphadenitis) adalah salah satu gejala utama dalam penyakit Kawasaki, biopsi kelenjar getah bening leher jarang dilakukan, karena penyakit Kawasaki biasanya didiagnosis dengan gejala klinis. ${ }^{7}$ Diagnosis klinis berdasarkan adanya demam 5 hari, ditambah 4 dari 5 kriteria diagnostik berikut ini: (1) eritema bibir atau rongga mulut atau retak bibir, (2) ruam kulit, (3) pembengkakan pada tangan atau kaki, (4) mata merah (injeksi konjungtiva), dan (5) pembesaran getah bening di leher minimal 15 milimeter.

Selain itu, diagnosis dapat ditegakkan hanya berdasarkan terjadinya aneurisma arteri koroner, meskipun hal tersebut sudah sangat terlambat. Jika tidak ditangani, gejala klinis tersebut akan hilang, tetapi aneurisma pada arteri koroner di jantung akan menetap.

\section{PEMERIKSAAN LABORATORIUM}

Beberapa pemeriksaan penunjang medik pada penyakit Kawasaki dapat menunjukkan hasil sebagai berikut :
1. Darahtepiterlihatanemianormositik dan akhirnya trombositosis.

2. Tingkat sedimentasi eritrosit (laju enap darah) akan meningkat.

3. C-reaktif protein (CRP) akan meningkat.

4. Tes fungsi hati terdapat peradangan hati dan serum albumin rendah.

5. Elektrokardiogram (EKG) terlihat disfungsi ventrikel atau kadangkadang aritmia karena miokarditis.

6. Ekokardiogram (Echo) terlihat perubahan halus arteri koroner atau, kemudian aneurisma.

7. Ultrasound atau tomografi terkomputerisasi dapat menunjukkan hidrops (pembesaran) kantong empedu.

8. Urinalisis terlihat sel darah putih dan protein dalam urin (piuria dan proteinuria), tanpa disertai pertumbuhan bakteri.

9. Pungsi lumbal terlihat adanya meningitis aseptik.

10. Angiografi untuk mendeteksi aneurisma arteri koroner menjadi standar emas untuk diagnosis, tetapi sekarang jarang digunakan karena telah dapat diketahui dengan ekokardiografi.

Peningkatan kadar meprin A dalam urin, terlihat apabila ada lesi arteri koroner pada tikus model yang mengalami penyakit Kawasaki. Profil proteoma urin mengungkapkan penanda baru molekul bukti penyakit Kawasaki, termasuk filamin $\mathrm{C}$ dan meprin $\mathrm{A}$, yang menunjukkan peran dalam diagnostik penyakit Kawasaki yang sangat baik. Tanda klinis ini dapat meningkatkan akurasi diagnostik dan evaluasi klinis anak yang diduga mengalami penyakit Kawasaki, bahkan mengarah pada identifikasi sasaran terapi baru pada penyakit Kawasaki. ${ }^{8}$ 


\section{DIAGNOSIS BANDING}

Penyakit Kawasaki dapat didiagnosis banding dengan morbili (campak), reaksi obat, parotitis akut, Stevens Johnson Syndrome, demam skarlatina, infeksi streptokokus grop A beta hemolitikus, Staphylococcal Scalded Skin Syndrome dam Juvenile Rheumatoid Arthritis.

\section{PENGOBATAN}

Saat ini, pemahaman yang tidak lengkap dari patogenesis molekul, tentu saja menghalangi identifikasi target rasional yang diperlukan untuk meningkatkan keberhasilan terapi pada penyakit Kawasaki. ${ }^{8}$ Oleh sebab itu, anak dengan penyakit Kawasaki harus dirawat di RS dan ditangani oleh seorang dokter yang memiliki pengalaman dengan penyakit ini. IVIG (imunoglobulin per infus) sebaiknya diberikan dalam dosis tinggi, yaitu $2 \mathrm{gr} / \mathrm{kgBB}$ selama 10-12 jam, yang biasanya akan terjadi perbaikan dalam waktu 24 jam. Jika demam tidak turun, dosis tambahan mungkin harus dipertimbangkan. IVIG adalah obat yang paling berguna dalam 7 hari pertama demam, untuk mencegah terjadinya aneurisma arteri koroner. Terapi globulin-pengganti immune (immune globulin-replacement therapy) seperti IVIG itu, telah menjadi pengobatan sejak diperkenalkan pada 1950-an. Selain pada penyakit Kawasaki, immune globulin intravena mungkin juga memainkan peran aktif dalam penyakit immunodefisiensi primer lainnya. ${ }^{9}$

Salisilat, terutama aspirin, tetap merupakan bagian penting, meskipun salisilat saja tidak seefektif IVIG. Terapi aspirin dimulai pada dosis tinggi 80-100 $\mathrm{mg} / \mathrm{kgBB} /$ hari dalam 4 dosis sampai 2-3 hari demam mereda, dan kemudian dilanjutkan dengan dosis rendah 3-5 mg/kgBB/hari, ketika pasien diijinkan pulang ke rumah. Biasanya diberikan selama 2 bulan untuk mencegah pembentukan gumpalan darah (trombus) dan dihentikan jika pmeriksaan ekokardiografi tidak lagi menemukan kelainan koroner. Aspirin jangka panjang sebenarnya tidak direkomendasikan untuk anak karena berisiko terjadinya sindrom Reye.

Kortikosteroid juga telah digunakan, khususnya bila pengobatan lain gagal atau gejala-gejala kambuh, tetapi dalam uji coba terkontrol secara acak, penambahan kortikosteroid untuk IVIG dan aspirin tidak memperbaiki hasil terapi. Pengobatan lain adalah infliximab (Remicade) yang bekerja dengan jalan meningkatkan TNF-A (Tumor Necrosis Factor Alfa). Pasien dengan penyakit Kawasaki yang mengalami komplikasi pada jantung, dapat berupa lesi arteri koroner yaitu aneurisma dengan kalsifikasi dan trombus. Pada keadaan seperti ini, pasien memerlukan tindakan operasi bypass arteri koroner, dengan arteri mamaria interna kiri sebagai pilihan pertama bypass graft, karena patensi dan kelangsungan hidup pasien jangka panjang cukup memuaskan. ${ }^{11}$

\section{PROGNOSIS}

Dengan terapi awal, gejala akut dapat diatasi dan risiko aneurisma arteri koroner sangat berkurang. Meskipun tidak diobati, sebenarnya gejala penyakit Kawasaki yang akut juga membaik, tetapi risiko terjadinya aneurisma arteri koroner jauh lebih besar. Secara keseluruhan, sekitar 2\% pasien akan meninggal karena komplikasi nodular koroner. Secara keseluruhan, komplikasi yang mematikan pada pasien yang telah mendapatkan terapi dini sangat langka, dibandingkan dengan yang tidak. Pasien dengan penyakit Kawasaki seharusnya diperiksa EKG pada tahap awal, setiap beberapa minggu, dan kemudian setiap 
1 atau 2 tahun, untuk pemantauan komplikasi pada jantung.

\section{PENCEGAHAN}

Tidak dikenal cara pencegahan untuk penyakit Kawasaki. Pencegahan dilakukan untuk menghindari perburukan kerusakan koroner. Orangtua anak penderita penyakit Kawasaki dengan kelainan koroner, ditekankan tentang perlunya tindak lanjut, yaitu minum obat secara teratur dan pemantauan kondisi jantung. Pengamatan penderita paska penyakit Kawasaki, terutama dengan riwayat aneurisma koroner berat, dilakukan jangka panjang bahkan mungkin seumur hidup. Aneurisme koroner yang ringan pada umumnya akan mengalami resolusi dalam beberapa bulan. ${ }^{12}$

\section{PENUTUP}

Semoga akan terjadi pemahaman yang lebih baik bagi kita semua tentang penyakit Kawasaki ini.

\section{DAFTAR PUSTAKA}

1. Onouchi, Y., Ozaki, K., Buns, J., Shimizu, C., Hamada, H., Honda, T., Terai, M. 2010. Common variants in CASP3 confer susceptibility to Kawasaki disease, Human Molecular Genetics, Vol. 19, No. 14 2898-2906, doi:10.1093/hmg/ddq176.

2. Lee, K., Rhim, J., and Kang, J. 2012. Kawasaki Disease: Laboratory Findings and an Immunopathogenesis on the Premise of a "Protein Homeostasis System". Yonsei Med J, 53 (2): 262-275.

3. Yu-wen, L., Wang, J., Sun, L., Zhang, J., Cao, L., Ding, Y., Chen, Y., Dou, J. 2015. Understanding the Pathogenesis of Kawasaki Disease by Network and Pathway Analysis, Computational and Mathematical
Methods in Medicine, Volume 2013, Article ID 989307, 17 pages, http:// dx.doi.org/10.1155/2013/989307.

4. Kuo, H., Huang, Y., Chien, S., Yu, H., Hsieh, K., Hsu, Y., Chang, W. 2014. Genetic Variants of CD209 Associated with Kawasaki Disease Susceptibility. PLOS ONE | www. plosone.org 1 August 2014 | Volume 9 | Issue 8 | e105236.

5. http://www.news-medical.net/ health/Kawasaki-Disease

6. Kuwabara, M., Yashiro, M., Kotani, K., Tsuboi, S., Ae, R., Nakamura, Y., Yanagawa, H., and Kawasaki, T. 2015. Cardiac Lesions and Initial Laboratory Data in Kawasaki Disease: a Nationwide Survey in Japan J Epidemiol;25(3):189-193, doi:10.2188/jea.JE20140128.

7. Katano, H., Sato, S., Sekizuka, T., Kinumaki, A., Fukumoto, H., Sato, Y., Hasegawa, H., Morikawa, S. 2012. Pathogenic characterization of a cervical lymph node derived from a patient with Kawasaki disease, Int J Clin Exp Pathol;5(8):814-823 www.ijcep.com /ISSN:1936-2625/ IJCEP1208021.

8. Kentsis, A., Shulman, A., Ahmed, S., Brennan, A., Monuteaux, M., Lee, Y., Lipsett, S. 2013. Urine proteomics for discovery of improved diagnostic markers of Kawasaki disease, EMBO Mol Med, 5, 210-220, DOI 10.1002/ emmm.201201494.

9. Jaggi, P., Kajon, A., Mejias, A., Ramilo, O. and Leber, A. 2015. Human Adenovirus Infection in Kawasaki Disease: A Confounding Bystander? CID 2013:56 (1 January), downloaded from http:// cid.oxfordjournals.org/ by guest on June 11, 2015. 
10. Gelfand, E. 2012. Intravenous Immune Globulin in Autoimmune and Inflammatory Diseases. N Engl J Med;367:2015-25. DOI: 10.1056/ NEJMra1009433.

11.Yuan, S. 2012. Cardiac surgical procedures for the coronary sequelae of Kawasaki disease, Libyan J Med, 7: 19796 - http://dx.doi.org/10.3402/ ljm.v7i0.19796.
12.Pujiadi, A., Hegar, B., Handryastuti, S., Idris, N., Gandaputra E., Harmoniati E., Yuliarti, K (ed). 2011, Pedoman Pelayanan Medis IDAI, Jilid II, Jakarta, pp 150-3. 